\title{
The different Perspectives of Christianity and Paganism on the Concept of Revenge in Shakespeare's Hamlet
}

\author{
Mustafa Mohammed Rashid
}

Asst. Instr. Department of English, Al-Turath University College, Baghdad, Iraq

\begin{abstract}
This paper focuses on the question of Hamlet's potential actions, especially after the meeting with the Ghost of his passed away father. The main focus is on the prominent influence of biblical and Christian doctrine on the behavior of Hamlet as he seeks revenge, and how biblical and Christian doctrine play an important role in changing the course of events in the play. Moreover, Shakespeare uses the biblical and Christian teachings subtly and substantially. Therefore, he achieves that by presenting Hamlet as a pious Prince who wants to make sure whether his uncle has murdered his father or not, which is almost similar to the historical and religious story of Cain and Abel. Moreover, the concept of remembrance in Catholicism will be taken under the consideration. Furthermore, the controversial characteristics of Hamlet show the syncretism of Catholic and Protestant sects of Christianity as represented by the religious culture of Elizabethan era.
\end{abstract}

Keywords-Hamlet, Christianity, Protestant, Catholic and revenge.

\section{INTRODUCTION}

This paper aims at demonstrating that, essentially, Hamlet's dilemma which he suffers from throughout the whole play which is also fundamentally related to his blind belief in Christianity. This paper shows how through the course of events in the play and the behaviors of Hamlet as a protagonist of the play, Shakespeare is capable of creating dramatic tension for dramatic purposes. This paper shows in detail the engagement of Hamlet with Christian theology in the reformation era in England, which is still under the influential beliefs of Catholicism.

Shakespeare engages the religious doctrine with Hamlet in order to increase the tension dramatically. For example, when the Ghost appears before Hamlet for the first time, it informs him about life of Purgatory which is so dreadful but mortals like Hamlet are not allowed to know anything about it. It adds that Purgatory can make one's hair stands upright like a Porcupine. Therefore, the Ghost's appearance and the description of Purgatory life lead the audience, the readers and the theists to hold their breath, as if they are watching a horror movie or a thriller.

Shakespeare shrewdly establishes an immovable Christian faith in Hamlet in order to revive the inner conflict in him, especially when he faces an avoidable mission to seek revenge. In Hamlet, Shakespeare tries to explore the modern rift and the huge gap between Catholics and Protestants. Shakespeare also tries to have Hamlet invoking both sects in order to serve his dramatic aims as well as enabling him to be closely observed by the audience. Shakespeare wants to show Hamlet as a half Catholic and a half Protestant, although where possible there will be a recognition between the two strains. In Hamlet, the major themes and subjects such as suicide, murder and revenge which are condemned by both Catholic and Protestant sects unanimously.

\section{THE EXTENSIVENESS OF HAMLET'S BIBLICAL IMPLICATIONS}

Through the various soliloquies of Hamlet, Shakespeare tries to show Hamlet's inner conflict and motivations in order to evolve the course of events gradually in the play. In the first act, the audience are introduced to Hamlet as a motivated young prince who would be eager and willing to commit suicide if it were not forbidden by almost all of the religions including Christianity. Therefore, Hamlet continuously takes his Christian belief in important decisions of life and death under the consideration. Shakespeare uses the extensive Christian theology in the play in order to be understood and noticed by his audience for whom "Christian language pervaded oral, written and printed discourse..." (Shell, 2011, p.4) Despite the fact that the majority of Shakespeare's audience are illiterate but they go to the church on Sundays and the other holy days. Therefore, it is normal to see Hamlet depends on the Holy Bible till the end of the play in order to seek the idea of providence in taking revenge. It is true that in his first soliloquy, Hamlet 
shows how deep he is committed to the Bible and the Christian doctrine.

It is also very true that in his first soliloquy He likens the state of Denmark to " Unweeded garden " that has fallen from Paradise as a pure state or like the father of nations Prophet Adam peace and blessings of Allah be upon him (Hibbard, 2008, p.50). Therefore, in the moment Shakespeare introduces the character of Hamlet, it shows that he will follow the Bible literally and it will become his absolute reference point. So, the audience will be able to predict that Hamlet's theological thinking and behavior will be dominant from the beginning to the end of the play. Everything in Hamlet's life is a matter of to be or not to be, whether to keep his love for Ophelia or to let her down, whether to take revenge or to let it slip by, whether to respect his mother or to criticize her as sharp as a dagger for her quick marriage from his uncle which he considers it an incestuous act. Therefore, he wishes to commit suicide because he cannot bear to live in Denmark which he considers a big jail with lots of cells and dungeons but on the other hand he cannot commit suicide because it will lead him to the eternal damnation according to Christianity and almost all of other religions.

In a turning point, Hamlet refers directly to biblical verses for hilarious purposes when he refers to Polonius as Jephthah, judge of Israel, when he strangely mentions to Polonius "O Jephthah, judge of Israel, what a treasure hadst thou!" (Shakespeare, 2008, p.70), but it also foresees Ophelia's death which is something the audience cannot predict it.

The religious story of judge of Israel is mentioned in the book of Judges in the Bible. At the first place, Hamlet alludes to a biblical verse which describes Jephthah the brave man as "the son of an harlot...." (Shakespeare, 2008, p.70) his half-brothers who are from the same father, Gilead, but from a different mother, consider him an outcast because of his illegitimate birth. Moreover, the Gileadites have been attacked by invaders so they ask Jephthah for help. So, he swears and promises God that if he wins the battle and gets back home safely then "whatsoever cometh forth of the doors of my house to meet me .. shall surely be the Lord's, and I will offer it up for a burnt offering" (Judges, 2001, p. 31). Unexpectedly, his daughter comes out of the door first to greet her father. So, Jephthah doesn't like to be a promise breaker. Therefore, he kills his daughter. Here, it is foreshadowing, because Hamlet knows very well that Polonius uses his daughter for nothing but flattery and to get closer to the royal family, especially Claudius, the king. It's obvious that Polonius is a flatterer to the king and ready even for sacrificing his daughter for the sake of his position. What's more, Polonius is such a contradictory character because at first, he gives strict orders to his daughter Ophelia to leave Hamlet and spend less time with him because he is a prince and out of her league, but then, when he finds that the king is so curious and interested in finding out the reason behind Hamlet's craziness. So, he tries his best to please the king by telling him that the reason behind Hamlet's weird behavior is his unrequited love for Ophelia. This shows without a doubt that he exploits his daughter for his own interest.

All in all, Hamlet's implications to the biblical verses play an important role in the whole course of events in the play. These allusions show that Hamlet is constantly relying on the Bible in almost everything in times of happiness and mocking others like Polonius and in times of sadness and grief when he thinks of suicide, revenge, sin and his uncle's premeditated murder. Therefore, what makes Hamlet a unique play is Hamlet's obsessions by his religious and doctrinal beliefs.

\section{THE EFFECTIVENESS OF CHRISTIANITY IN HAMLET'S REVENGE}

The Christian religion and paganism have been intersected during the renaissance era. Renaissance thinkers have revived the classical works by appraising them from immanent Christian perspectives. On the other hand, there are many pagan morals and virtues like endurance and stoicism which are somehow similar to some Christian morals. But still there are many Christian extremists who believe that any lesson from pagans will be considered a heresy. Despite the fact, that Christians and pagans have so many virtues in common but there are also certain points of disagreement. For example, the concept of revenge is a controversial and contentious issue between Christians and pagans which may revive the conflict of positions and what makes the conflict more complicated is the foggy picture of the Old Testament on the idea of Revenge.

Shakespeare impresses his audience by playing on the same conflict. Therefore, it is obvious through the appearance of the Ghost when it informs Hamlet to seek revenge and work on it by following the Christian values, especially when it tells Hamlet not to harm his mother but leave her to God and to focus on Claudius: "But howsoever thou puruest this act / Taint not thy mind.." (Shakespeare, 2008, p.84). Hibbard (2008) believes that Hamlet should not follow the immoral and roundabout means of Claudius while seeking revenge. The Ghost gives a contradictory command for revenge and this command elevates Hamlet's inner conflict.

Reading the Ghost's lines in the play shows that it orders Hamlet to focus on two main things: the first thing is not to 
harm his mother and the second one is to bring his uncle to justice and not to taint his mind by doing a foul play.

Therefore, the Christian way of seeking revenge is nothing but seeking justice in the course of events. It is clear that what makes Hamlet distinctive and different from other revenge plays is that it is driven by the Christian doctrine, unlike other plays which include avengers who are pagans or those who have a bloody will to cross the limits of the Christian injunction against the concept of revenge. Therefore, there is a great possibility to compare Titus Andronicus with Hamlet in which two characters Tamora and Titus are parched with thirst for seeking a brutal revenge by following deceitful means. So, they are similar to Claudius and Laertes who try to kill Hamlet in the course of events . Claudius tries to get rid of Hamlet by sending him off to England in order to get killed by the king of England who will receive Claudius' letters which inform him to kill Hamlet but this plan hasn't succeeded. Therefore, Claudius exploits Laertes' grieve over his father's death and his sister's insanity in order to push him to kill Hamlet and that means that both Claudius and Laertes resort to bloody means. But on the contrary, neither Hamlet resorts to these deceitful means nor the Ghost's instructions include these bloody acts in seeking revenge because of their strong belief in Christianity.

Here, Shakespeare shows that Christianity explicitly forbids Christians from seeking revenge privately. Therefore, there are two opposite worldviews. Laertes represents the pagan worldview in mocking the Christian mores, especially when he insults the priest in Ophelia's funeral but that doesn't make him a malicious character but a dutiful son who wants to regain his father's dignity. While Hamlet represents the Christian worldview in following the Christian mores, especially when he wants to make sure whether the Ghost is genuine or maybe a devilish spirit wants to seduce him to commit a crime and to lead him to an eternal damnation.

When Laertes returns to Denmark to inquire about his father's death he has completely gone a bloodthirsty avenger: " $\mathrm{O}$ thou vile King, Give me my father" (Shakespeare, 2008, p.113). Even when the Queen urges him to cool down, he replies angrily: " That drop of blood that's calm proclaims me bastard, Cries cuckold to my father...." (Shakespeare, 2008, p.116). Therefore, Laertes invokes paganism to justify his vengeful wrath. He adds that because he is his only father's son, he will seek revenge.

Laertes has become a furious avenger when he finds out that his father has been killed and then his sister has committed suicide by drowning herself in the river. However, he is absolutely dissatisfied with the Christian
God and mentions: " Do you see this, O God?" (Shakespeare, 2008, p.201).

Obviously, Laertes believes that God of Christians must be deaf or blind by doing nothing to put an end to the catastrophe that his family suffers from. Moreover, he has become more furious when the priest refuses to perform more Christian rites because the priest believes that Ophelia should be buried outside the church graveyard because She has committed suicide and if he reads more rites, it will profane the other graves and that drives Laertes up the wall and insults the priest and the church:

Lay her I'th earth,

And from her fair and

unpolluted flesh

May violets spring. I

tell thee, churlish priest,

A minist' ring angel

shall my sister be

When thou liest howling

(Shakespeare, 2008, p.228)

Hibbard (2008) thinks that Laertes believes that the priest is going to be howling in hell for his misbehavior of his sister's burial. However, that shows how deeply he abhors the church and Christianity in general, especially when Claudius asks him what will he do when he faces his father's murderer, Laertes responses that he promises to "Cut his throat I'th' church" (Shakespeare, 2008, p.103). Despite the fact that he rejects the Christian worldview, but the audience sympathize with him. "The ability to evoke sympathy and understanding for a diverse range of characters" (Shell, 2011, p. 128). Shakespeare shows that Laertes' revenge has nothing to deal with Christianity in order to shed light on the hesitancy of Hamlet which shows the great commandments which he has to keep. Therefore, he is different from Laertes because of his Catholic and Protestant beliefs.

David (2006) thinks that the significance of Hamlet's university life is an important point in his Christian belief: "Wittenberg is where Martin Luther had posted his celebrated 95 theses to the church door in 1517 and where he had met William Tyndale in 1524..." (p.63). While Stein thinks that a very small number of people from noble families attended universities " For Shakespeare to prolong Hamlet's studies into manhood renders what was already unusual even more so ...." (p.55).

Shakespeare shows the character of Hamlet as a true believer in the Christian doctrine, especially when he suffers from many tragedies like his father's death and his mother's quick marriage, he doesn't reject his great faith but on the contrary he prefers to stick to it. 
Hamlet objects to the quick marriage of his mother from his uncle for he considers it an incestuous marriage which is driven from his Christian belief. For example, Mosaic Law in The Old Testament considers incest a nasty violation. Also, book of Leviticus considers sexual relations with various close relative a forbidden thing. Furthermore, Leviticus stresses: "And if a man shall take his brother's wife, it is an unclean thing: he hath uncovered his brother's nakedness: they shall be childless" (Judges, 2001, p.21).

Hamlet echoes Catholicism, especially when he tells his close friend Horatio that he has forged Claudius' letters instructing the English authorities that his untrustworthy friends Guildenstern and Rosencrantz should be killed immediately. Therefore, Hamlet's shriving refers to confession of sins before a priest to receive forgiveness. As if Hamlet wants to imply that English people have a great knowledge of Catholicism. In his way to England, Hamlet meets a Captain who informs Hamlet that his army marching in order to attack Poland and retake a small piece of land which is worthless. So, Hamlet delivers an amazing soliloquy that begins: "How all occasions do inform me, And spur my dull revenge!" (Shakespeare, 2008, p. 32).

Analytically, Shakespeare, in his dramatic ways, refers to the last supper of Jesus Christ peace and blessings of Allah be upon him when Hamlet returns from England he meets his friend Horatio where they talk with a gravedigger who digs Ophelia's grave in the church graveyard. In this conversation, the gravedigger couldn't recognize that he speaks with Hamlet which refers to Jesus when he tells his companions that he will survive: " For just as Jonah was three days and three nights in the belly of the great fish, so the Son of Man will be three days and three nights in the heart of the earth" (Matthew, 2001, p.40). When Jesus returns from the graveyard wearing a gravedigger's uniform to hide himself from the Jewish authorities, he walks into the place of his students who think that Jesus has been crucified, so when he meets them, they get terrified, however, one of the students says this is The Holy Spirit, but Jesus wants to prove that they are mistaken by telling them that he is starving, so they offer him fish and honey. This biblical story contradicts another story in the Bible which goes: "and He died for all, that those who live should no longer live for themselves, but for Him who died for them and was raised again" (Corinthians, 2001, p.15).

At the end, Shakespeare's Hamlet is different from most of revenge plays of his time which base on the Senecan way in seeking a bloody revenge. But revenge in Hamlet bases on Hamlet's Catholic and Protestant beliefs.

\section{THE CATHOLIC CONCEPT OF REMEMBRANCE IN HAMLET}

Hamlet is constantly reminded of taking revenge by the purgatorial ghost who focuses on remembrance more than revenge. It is obvious that the Ghost repeats the word "remember" over and over again. In this scene, Greenblatt (2001) thinks that this is a shifting point in Hamlet's life from revenge to remember. Therefore, Shakespeare wants to lead his audience to think about Hamlet's mind and conscience .

The concept of remembrance is in Catholicism in which helping the dead through prayers of remembrance in order to ease their purgatorial torture, especially if they die while enjoying life to the full, just like the dead king of Denmark which happens to appear as a Ghost. In the tragic scene, both the purgatorial Ghost and Hamlet refer to the injustice that has been taken place in Denmark and that Claudius must be put to death for his Cain and Abel murder. There are so many remembrance stories in English literature where dead characters urge the surviving ones to keep remembering them or revive their memory. For example, in Odyssey , Obysseus' mother " wishes her story to be known and remembered in the world of living.." (Casey, 1990, p. 85). Kearney (2005) thinks that there is a great possibility that the Ghost wants to say: "Tell my tale and transmit my memory to future generations..." (p.158). Greenblatt (2001) thinks that Shakespeare's sensitivity is what led him to be creative in writing about the concept of remembrance, especially after his son's death as well as his father' one. Therefore, Hamlet has no specific Christian sect to follow because he goes to a Protestant college but he is also satisfied with the purgatorial ghost of his father who believes in the concept of remembrance which is a Catholic rite.

\section{CONCLUSION}

It's been concluded that Shakespeare uses the Christian doctrine in order to enrich his dramatic means in the play, especially by focusing on the purgatorial life of the Ghost in the play. Shakespeare has written the play in order to ruin the Protestant worldview by using Catholic characters. Therefore, he wants people to adopt both Catholic and Protestant ways of life and not to focus only on the contradictions of the two. Shakespeare uses Hamlet to represent the syncretism in Christianity by shedding light on the religious controversy in order to impress his audience and capture their attention. Because the audience will be forced to think about the contradictory concepts of revenge in the biblical verses. For example, the Old Testament urges people to seek revenge by following the 
concept of eye by eye and teeth by teeth, while the New Testament urges people to seek forgiveness by following the concept of if someone slaps you on one cheek, turn to them the other also, which means that the New Testament rejects the private revenge. Shakespeare also uses Hamlet and Laetes to allow the audience to figure out the differences between Pagan and Christian worldviews on the concept of revenge.

Shakespeare also presents the concept of remembrance in Catholicism through Hamlet and the Ghost in which the Ghost urges Hamlet to remember it which is a Catholic concept in which those who are still alive should remember those who have passed away in order to ease their purgatorial life.

\section{REFERENCES}

[1] The Bible (2001). Authorized King James Version. Thomas Nelson Bibles. Belgium: Thomas Nelson Inc. pp.31-34. Casey, J. (1990). Pagan Virtue: An Essay in Ethics. Oxford: Clarendon Press. pp.80-85.

[2] David, D. (2006). The Explorers of the Revelation: Spenser and Shakespeare. Shakespeare's Christianity: The Protestant and Catholic Poetics of Julius Caesar, Macbeth, and Hamlet. Ed. Beatrice Batson. Waco, TX: Baylor University Press. pp.19-63.

[3] Greenblatt, S. (2001). Hamlet in Purgatory. Princeton: Princeton University Press.

[4] Hibbard, G. R. (2008). Introduction. Hamlet. Ed. G.R. Hibbard. Oxford: Oxford University Press. pp.50-56.

[5] Shakespeare, W. (1998). Hamlet. Ed. Sylvan Barnet. New York: Signet Classics.

[6] Shakespeare. W. (2008). Hamlet. Ed. G.R. Hibbard. Oxford: Oxford University Press. pp.32-228.

[7] Shell, A. (2011). Shakespeare and Religion. London: Bloomsbury Arden Shakespeare. pp.4-128. 